\title{
MONITORING RESULTS OF A COMBINED PELLET AND SOLAR HEATING SYSTEM
}

\author{
Frank Fiedler \\ Solar Energy Research Center SERC, \\ Högskolan Dalarna, S-78188 Borlänge, Sweden \\ ffi@du.se
}

\author{
Chris Bales \\ Solar Energy Research Center SERC, \\ Högskolan Dalarna, S-78188 Borlänge, Sweden
}

\author{
Johan Vestlund \\ Solar Energy Research Center SERC, \\ Högskolan Dalarna, S-78188 Borlänge, Sweden
}

\begin{abstract}
In this study the monitoring results of prototype installation of a recently developed solar combisystem have been evaluated. The system, that uses a water jacketed pellet stove as auxiliary heater, was installed in a single family house in Borlänge/Sweden. In order to allow an evaluation under realistic conditions the system has been monitored for a time period of one year.

From the measurements of the system it could be seen that it is important that the pellet stove has a sufficient buffer store volume to minimize cycling. The measurements showed also that the stove gives a lower share of the produced heat to the water loop than measured under stationary conditions. The solar system works as expected and covers the heat demand during the summer and a part of the heat demand during spring and autumn. Potential for optimization exists for the parasitic electricity demand. The system consumes $680 \mathrm{kWh}$ per year for pumps, valves and controllers which is more than $4 \%$ of the total primary heating energy demand.
\end{abstract}

\section{INTRODUCTION}

Solar heating systems that provide domestic hot water and space heating, so called solar combisystems, have become more and more popular in the Middle and Northern European countries. Solar combisystems usually require an auxiliary heat source to be able to provide enough heat even in the seasons with low solar irradiation. In Sweden, electrical heaters and wood boilers are typically used as auxiliary heaters in solar combisystems. In recent years wood pellet boilers and stoves have also become a good alternative. The design of solar combisystems has been studied intensively in the IEA-SHC Task 26 "Solar combisystems". A number of systems have then been, based on system simulations, optimised and improved. The results from Task 26 including a variety of technical reports and design tools are available for the public (6).
Within the Nordic research project REBUS a new combined solar and pellet heating system for the Nordic market has been designed, built and tested (4). During this project typical existing system solutions for this combination have been investigated by the help of measurements and computer simulations (2). It has been shown that these system solutions, due to their design and size, are often not suitable for typical Swedish houses without heating room. Also the thermal performance, such as heat losses and solar savings, offered potential for improvements. These finding have been included for the design of the new system. The first prototype of the REBUS system was tested intensively in the lab. The second improved prototype was installed in a single family house and has been monitored for a time period of one year.

\section{SYSTEM DESCRIPTION}

The REBUS system concept consists of two compact units; the solar store unit and the technical unit that contain the hydraulic components including the pellet boiler and an auxiliary store for the hot water production (see also figure 2). Both units are built in cabinets of $60 \mathrm{~cm} \times 60 \mathrm{~cm}$ (width, depth) which are the standard dimensions for kitchen and bathroom units like refrigerators and washing machines. The system uses a $12 \mathrm{~kW}$ water jacketed pellet stove with an internal water volume of 20 litre. The stove heats an auxiliary standby store and the upper part of the solar buffer store. The solar store comprises a water volume of 360 litre and has, due to high efficient vacuum insulation at the hottest parts of the store, a low UA-value of about $1.8 \mathrm{~W} / \mathrm{K}$. The solar system can provide heat to both stores. Instead of the separate water jacketed pellet stove, an integrated or separate pellet boiler can be used without any changes in the hydraulic layout. The system is equipped with one central controller with a specifically developed software for the control for all system components except the pellet stove. A detailed description can be found in (2). 

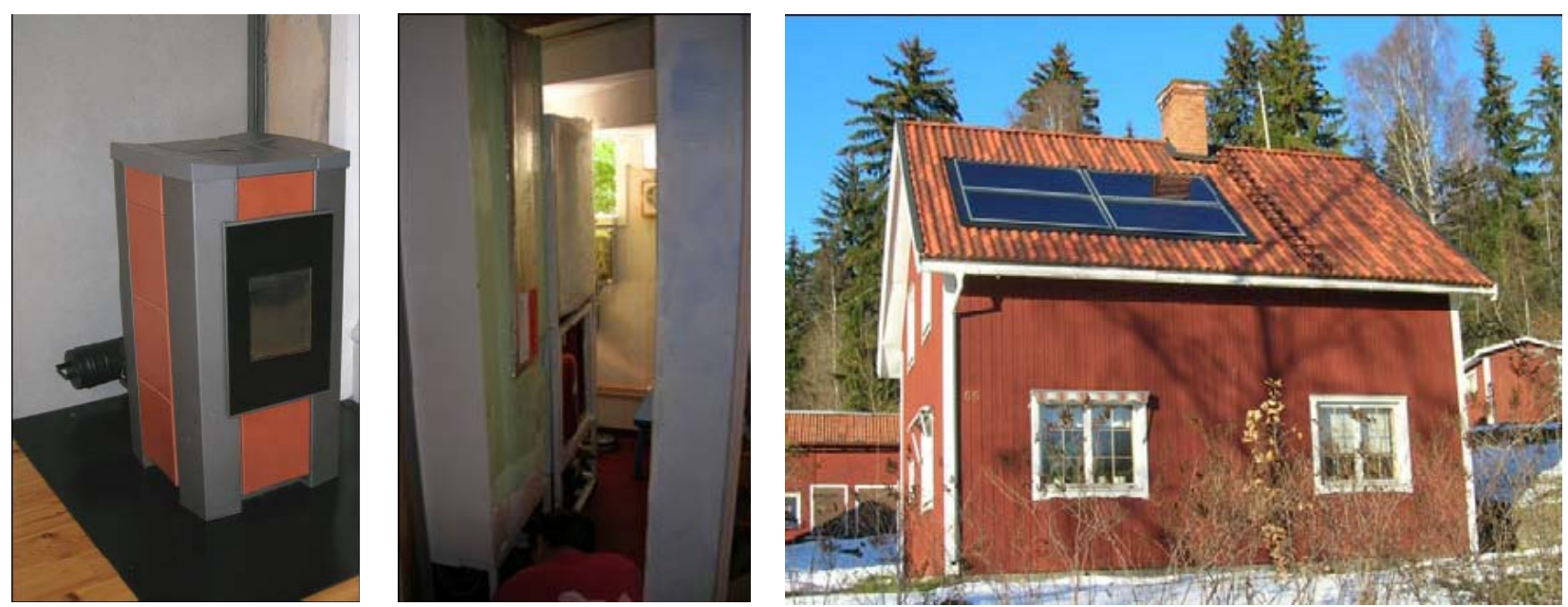

Fig. 1: The demonstration site in Borlänge, with (left) water jacketed stove, (middle) technical and store units in a bathroom under the stairs, and (right) view of the $10 \mathrm{~m}^{2}$ collector array on the roof.

In July 2006 a prototype of the REBUS system was installed in a single family house in Borlänge/Sweden that had earlier been heated with electrical radiators. In the main house these heaters were replaced by water based radiators. First the two units were installed without a pellet heater. In the middle of October 2006 the water jacketed pellet stove was added in the living room where a chimney was accessible. Up until this point a $6 \mathrm{~kW}$ electrical heater in the 80 litre standby store in the technical unit was used as the auxiliary heater. The stove has an integrated $38 \mathrm{~kg}$ pellet store which is fed manually by the owners (see Figure 1, left). The technical and store units were installed in a small room that earlier was used as a second bath room. (see Figure 1, middle). The collector field of $10 \mathrm{~m}^{2}$ (Figure 1, right) consists of four modules of Svesol premium AR with a standard rated output of $465 \mathrm{kWh}$ in Stockholm at constant $50^{\circ} \mathrm{C}$. It was placed on the main roof facing $40^{\circ} \mathrm{E}$ with a slope of $40^{\circ}$.

\section{MONITORING}

Monitoring started at the end of July 2006, thus results are presented for August 2006 onwards.

The heat flows in all hydraulic loops have been measured with calibrated sets of flow meters and temperature sensors. The air flow through the stove has not been measured. Instead, the measured values from the lab for the stove efficiency have been used to calculate the flue gas heat losses based on measured pellet use. Heat transferred from the stove directly to the building was calculated as the balance of the pellet energy and the flue gas losses together with the measured heat transferred to the water loop. Two separate electrical meters were installed to log the electricity consumption of the system and the electrical auxiliary heater. A simple pyranometer has been used to measure the solar radiation. A number of temperature sensors have been installed to give additional information about the status of the system components and the functioning of the system. Figure 2 shows the REBUS system schematic with sensor positions. The electrical meters and the pyranometer are not shown. The data were logged using a Campbell CR10 data logger with attached multiplexers. Average data values were stored with an interval of one minute.

The owner has kept good records of bought energy for the year previous to the installation, and these values are presented in some of the figures. The amount of wood used was estimated by the user and the tiled stove was assumed to have an efficiency of $50 \%$.

\section{MONITORING RESULTS}

In Figure 3 the heating energy supply for the building is presented from January 2006 to June 2007. The data before the installation of the REBUS system are calculated from the readings of the house owner from the main electrical meter and his records of wood use. The electricity for heating has been calculated based on measured household electricity in 2007. It can be seen that almost all bought electricity for heating was replaced by pellet and solar energy. About $200 \mathrm{kWh}$ electricity were used by the electrical back up heater in the standby store in October 2006. The pellet stove was installed in the middle of October and not enough solar radiation was available, which explains the use of the electrical heater that month. Some electricity was also used in December 2007. Reason here was that the 80 litre standby volume heated by the pellet stove was too little to cover the peak heat demand so that the electrical heater in the standby store was backing up the heating. 


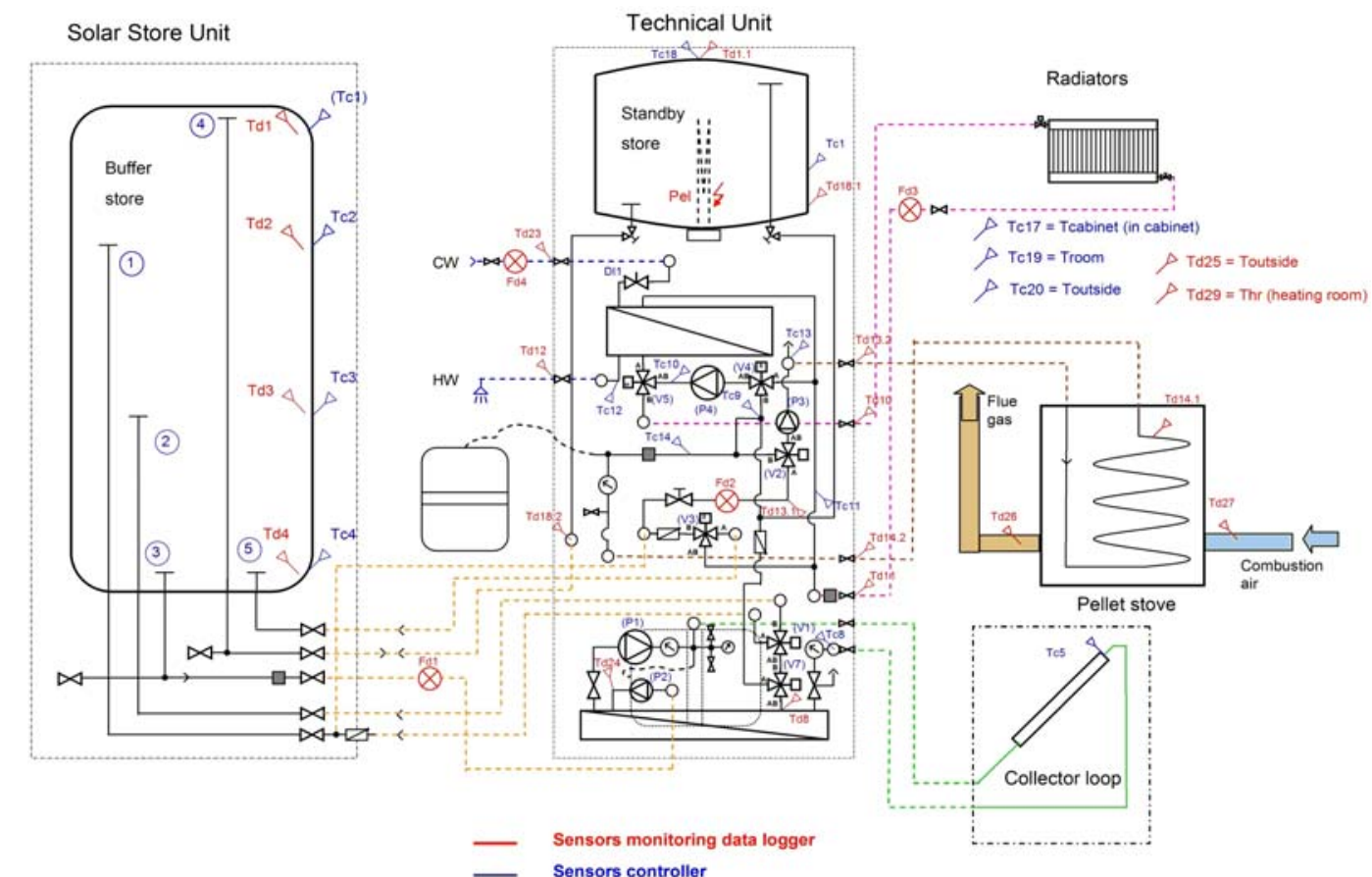

Fig. 2: REBUS system schematic with sensor positions for the REBUS controller (blue with subscript c) and the monitoring system (red with subscript d).

This has also caused a high number of starts and stops with stove run times often not more than one hour. Consequently in the end of December 2006, the hydraulics have been modified so that also the upper third of the solar store, which is connected in serial with the standby store, is heated by the boiler.

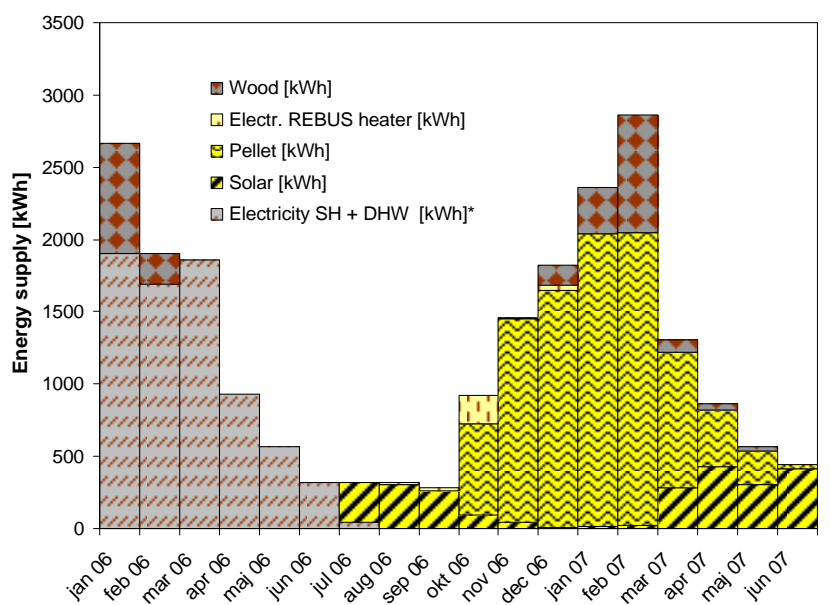

Fig. 3: Monthly heat supply for space heating and domestic hot water, *Electricity $\mathrm{SH}+\mathrm{DHW}$ is the calculated electricity use for $\mathrm{SH}+\mathrm{DHW}$ before the detailed monitoring.

This increases the standby volume to in total 200 litres. As a result of this modification it can be seen that the number of starts and stops have decreased drastically (Figure 4). The average run time increased to about 3 to 4 hours per start. Due to the longer run time of the stove also the proportion of the useful heat delivered from the stove to the water jacket has increased from $61 \%$ in December to $67 \%$ in January. This is still lower than the average $80 \%$ for the combustion range that is has been measured for the stove at the Austrian test institute BfL (1).

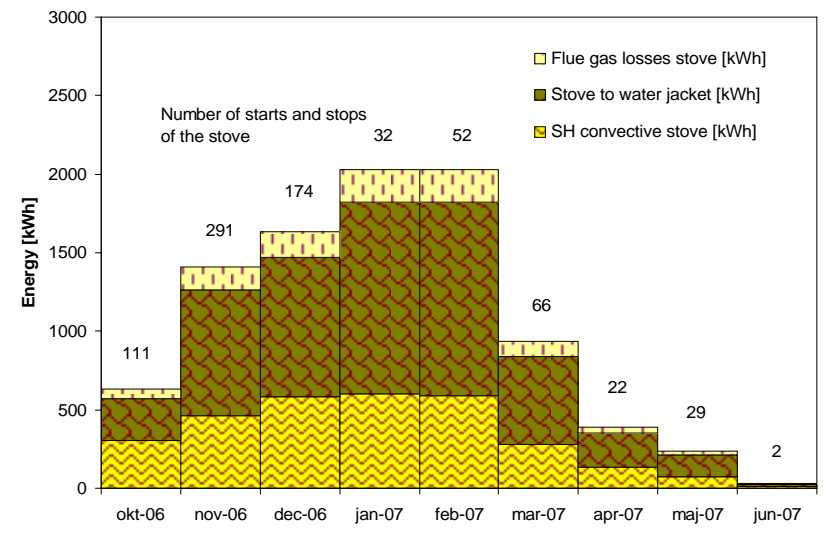

Fig. 4: Monthly heat delivery of the pellet stove and number of starts and stops.

In figure 5 the energy use for the monitored time period is presented. The monthly hot water demand varies between 240 and $400 \mathrm{kWh}$. The annual space heating demand is about $7400 \mathrm{kWh}$, which is relatively low for a building with 
a heated area of approximately $130 \mathrm{~m}^{2}$ and indicates a good thermal insulation.

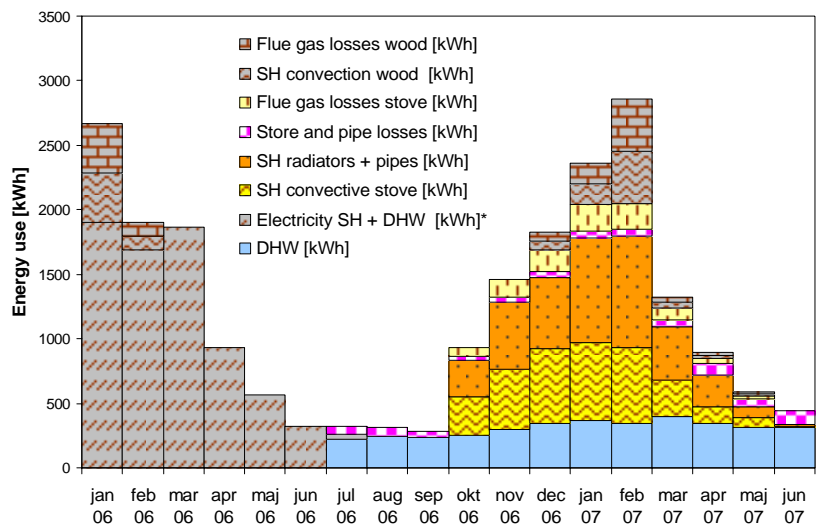

Fig. 5: Monthly heat use of the building, *Electricity $\mathrm{SH}+$ $\mathrm{DHW}$ is the calculated electricity use for $\mathrm{SH}+\mathrm{DHW}$ before the detailed monitoring.

During one year the solar collectors have delivered about $2529 \mathrm{kWh}$ which is a reasonable value considering the small solar store volume, the non-optimal orientation of the solar collectors and the low heat demand. In terms of bought energy this gives a solar fraction of $19 \%$.

Table 1: Annual heat supply and useful heat

\begin{tabular}{llll}
\hline $\begin{array}{l}\text { Annual heat supply } \\
(\mathrm{kWh})\end{array}$ & $\begin{array}{l}\text { Annual useful heat } \\
(\mathrm{kWh})\end{array}$ & \\
\hline Pellet & 9319 & Space heating & 7611 \\
Wood & 1434 & Hot water & 3673 \\
Solar & 2543 & & \\
Electricity & 278 & & 11284 \\
\hline Total & 13574 & & \\
\hline
\end{tabular}

\section{DISCUSSION AN CONCLUSION}

The newly developed solar combisystem has been monitored for one year. For the most part the system is working as expected. All loops and components are properly controlled by the new controller software. Only some fine adjustments of some parameters were necessary. Most adjustments were necessary for the settings of the pellet stove controller to ensure a proper interaction with the main system. A modification of the hydraulic connections was done to increase the buffer volume of the pellet stove. Using only the 80 litre volume of the standby store led to very short run times and many starts of the stove. After the change the run times of the stove increased and the number of starts and stops decreased drastically. Similar findings have been reported also in other studies $(3 ; 5)$.
From the annual energy values in Table 1 the system efficiency can be calculated using the following equation:

$\eta_{\text {sys }}=\frac{\text { annual useful heat }}{\text { annual supplied primary energy for heating }}$

With a primary energy factor of 0.4 for electricity the total system efficiency is 0.83 . Including also the parasitic electricity consumption of pumps, valves etc. decreases the system efficiency to 0.74 . The parasitic electricity of 680 $\mathrm{kWh}$ accounts for almost $5 \%$ or the total energy input to the system. It is obvious that the parasitic electricity consumption should be reduced e.g. by the use of more efficient pumps which stand for the main part of the parasitic consumption.

\section{ACKNOWLEDGMENTS}

We are grateful to the Nordic Energy Research and the Dalarna University College for their financial support for this work within the REBUS project.

\section{REFERENCES}

(1) BfL, "Prüfbericht Pelletskaminofen EVO AQUA." BLT Aktzahl: 053/04, Bundesanstalt für Landtechnik, Wieselburg, Austria. 2003.

(2) F. Fiedler, "Combined solar and pellet heating systems - Study of energy use and CO-emissions," PhD thesis, Mälardalen University, Västerås. 2006.

(3) F. Fiedler, C. Bales, and T. Persson, "Optimisation Method for Solar Heating Systems in Combination with Pellet Boilers/Stoves." International Journal of Green Energy, 4(3), 325 - 337. 2007.

(4) S. Furbo, A. Thür, C. Bales, F. Fiedler, J. Rekstad, M. Meir, D. Blumberga, C. Rochas, T. Schifter-Holm, and K. Lorenz, "Competitive Solar Heating Systems for Residential Buildings (REBUS)." Byg, DTU, Copenhagen, Denmark. 2006.

(5) A. Heinz, "Fortschrittliche Wärmespeicher zur Erhöhung von solarem Deckungsgrad und Kesselnutzungsgrad sowie Emissionsverringerung durch verringertes Takten." Technische Universität Graz, Institut für Wärmetechnik, Graz, Austria. 2006.

(6) IEA, "International Energy Agency - Solar Heating and Cooling Program." IEA-Task 26. 2002. 